\title{
Pengaruh Subjek dan Predikat dalam Pemahaman Teks Bahasa Arab
}

(The Influence of Subject and Predicate in Arabic Text Understanding)

\author{
AHMAD FuAd CHE DAUD@CHE MuD*
}

\begin{abstract}
ABSTRAK
Pemahaman merupakan objektif utama aktiviti membaca. Realiti hari ini, terdapat ramai pelajar pengajian bahasa Arab yang tidak mampu memahami teks dengan baik. Antara puncanya ialah kelemahan penguasaan ilmu tatabahasa. Kajian ini bertujuan untuk mengetahui pemahaman pelajar terhadap teks bacaan dan menganalisis pengaruh unsur tatabahasa subjek dan predikat terhadap pemahaman pelajar. Kajian ini menggunakan kaedah kualitatif dengan pendekatan kajian kes. Enam orang pelajar pengajian Ijazah Sarjana Muda Bahasa Arab dengan Pendidikan (ISMBADP) dari Universiti Pendidikan Sultan Idris (UPSI) menjadi peserta kajian ini. Data dikumpulkan melalui dokumen pemahaman teks dan temu bual. Dapatan kajian menunjukkan bahawa peserta kajian dapat memahami teks dengan baik. Temu bual yang dijalankan menunjukkan wujudnya pengaruh unsur tatabahasa subjek dan predikat terhadap pemahaman. Oleh itu, unsur subjek dan predikat merupakan aspek penting yang perlu diberi penekanan dalam pengajaran dan pembelajaran (P\&P) pemahaman teks bahasa Arab selain daripada kosa kata, kerana ia merupakan unsur asas binaan ayat.
\end{abstract}

Kata kunci: Aplikasi tatabahasa; subjek dan predikat; pemahaman; teks bahasa Arab

\section{ABSTRACT}

Understanding is a key objective of reading activities. The reality today, there are many Arabic language students unable to understand the text well. This inability caused from weak knowledge of grammar. Therefore, this study aimed at finding out the students 'understanding of a text and analyzing the influence of the subject and the predicate element in students' understanding. This study used qualitative methods with case studies. Six students of Bachelor of Arabic Language in Education (ISMBADP) at Universiti Pendidikan Sultan Idris (UPSI) has been a participant in this study. Data collected from understanding text documents and interviews. The results showed study participants can understand the text well. This interview shows the influence of the subject and predicate element in the text understanding. Thus, the elements of the subject and the predicate is an important aspect that should be emphasized in the teaching and learning of Arabic text understanding other than vocabulary, because it is a basic element of the structure of sentences.

Keywords: Grammer application; subject and predecate, comprehension Arabic text book

\section{PENGENALAN}

Pemahaman merupakan objektif utama dalam aktiviti membaca. Sesuatu bacaan tidak lengkap sekiranya pembaca tidak dapat memahaminya (Marohaini 1999). Namun, penguasaan pemahaman teks bahasa Arab dalam kalangan pelajar tidak mencapai objektif yang dikehendaki oleh Kementerian Pendidikan Malaysia (KPM) kerana kurangnya penekanan terhadap kaedah dan cara untuk mencapai pemahaman ketika aktiviti membaca. Kemahiran untuk memahami teks bacaan juga kurang mendapat perhatian dalam kalangan guru bahasa Arab berbanding kemahiran-kemahiran yang lain (Norazman 2006).

Proses memahami teks bacaan berbeza dengan memahami percakapan lisan. Melalui pembacaan, pelajar mampu berfikir dan meneliti teks yang dibaca. Lazimnya, pembacaan teks bahasa kedua memerlukan pembaca merujuk kepada kamus untuk mengetahui makna perkataanperkataan yang tidak difahami. Namun, unsur tatabahasa juga memainkan peranan yang penting bagi memastikan pemahaman yang baik dan tepat, terutamanya dua unsur asas binaan ayat, iaitu subjek dan predikat. Ia dikenali sebagai mubtada' dan khabar pada ayat nominal atau $f i$ ' $l$ dan fā 'il pada ayat verbal ('Abd al-Ḥāsib 2011). Seseorang pembaca pada mulanya harus dapat mengenal pasti dua unsur asas binaan ayat ini kerana ia merupakan kunci utama kepada pemahaman teks (Mohd Rosdi 2003).

\section{PERMASALAHAN KAJIAN}

Melihat kepada realiti pada hari ini, ramai pelajar bahasa Arab yang telah mendapat pendidikan asas di peringkat menengah tidak mampu untuk memahami teks bahasa tersebut dengan baik. Dalam satu kajian yang dijalankan kepada 135 orang guru pelatih di Institut Pendidikan Guru Kampus Pendidikan Islam, Bangi (IPGKPI) yang merupakan pelajar Program Persediaan Ijazah Sarjana Muda Pendidikan (PPISMP) dan Program Ijazah Sarjana Muda Pendidikan (PISMP) dalam bidang Bahasa Arab dan Pendidikan Islam mendapati, tahap pemahaman teks 
adalah sederhana (Sabri 2010). Menurut Kamarulzaman (2010), unsur kosa kata, sintaksis dan struktur ayat merupakan antara faktor utama yang menentukan tahap kebolehbacaan dan kefahaman terhadap teks selain daripada faktor pembaca. Dalam ujian kloz yang dijalankan kepada pelajar Sekolah Menengah Kebangsaan Agama (SMKA) dalam bidang bacaan teks bahasa Arab mendapati $96.47 \%$ responden berada pada tahap bacaan yang kecewa (Kamarulzaman 2011).

Norazman (2006) pula menyatakan masalah utama pelajar dalam pembacaan teks ialah kelemahan mereka membaca dengan kaedah tatabahasa Arab yang betul dari segi tanda baris dan tanda i'rab. Manakala, Nik Farhan (2011) merumuskan bahawa salah satu faktor yang membantu pembaca memahami teks dengan baik ialah penguasaan ilmu bahasa dan ilmu tatabahasa yang terdiri daripada sintaksis dan morfologi.

Semua kajian yang dibincangkan mendapati kebanyakan pelajar menghadapi masalah untuk memahami teks bahasa Arab yang dibaca. Antara puncanya ialah kelemahan mereka menguasai aspek tatabahasa. Namun, kajian-kajian tersebut tidak menyentuh secara khusus unsur tatabahasa yang mempengaruhi pemahaman pembaca. Oleh itu, kajian ini bertujuan untuk mengetahui pemahaman pembaca terhadap teks bacaan dengan melihat kepada pengaruh unsur tatabahasa subjek dan predikat, iaitu mubtada' dan khabar pada ayat nominal atau $f^{\prime} l \mathrm{l}$ dan fà 'il pada ayat verbal.

\section{KAEDAH KAJIAN}

Kajian ini merupakan kajian lapangan dengan menggunakan kaedah kualitatif dan pendekatan kajian kes. Seramai enam orang pelajar semester enam program Ijazah Sarjana Muda Bahasa Arab dengan Pendidikan (ISMBADP) di Universiti Pendidikan Sultan Idris (UPSI) telah menjadi responden kajian ini. Antara kriteria pemilihan peserta kajian ialah pelajar tahap cemerlang dan baik dalam bidang bahasa Arab. Pengkaji menetapkan kriteria ini kerana pelajar tahap ini kebiasaannya menguasai ilmu tatabahasa yang asas serta mampu untuk mengaplikasikannya (Nik Farhan 2011).

Pemilihan instrumen kajian pula melibatkan teks pemahaman yang terdapat dalam buku teks bahasa Arab tingkatan empat terbitan KPM. Pengkaji memilih teks bacaan dengan tahap kebolehbacaan yang sederhana dan sesuai dengan peserta kajian dengan sedikit ubah suai. Kebolehbacaan teks ini diukur dari sudut linguistik iaitu dengan melihat kepada penggunaan perkataan dan struktur ayat. Faktor ini merupakan faktor paling penting berbanding faktor pembaca (Zulazhan et al. 2009). Kebolehbacaan dan kesesuaian teks juga diukur berdasarkan bilangan perkataan dalam teks yang diuji. Menurut Tu'aymat (1990), Teks bacaan yang dipilih hendaklah mengandungi paling kurang 250 perkataan.

Setelah membuat penilaian teks berdasarkan kriteria tersebut, pengkaji memilih teks yang bertajuk “al-'Usrat
Madrasat " yang merupakan satu teks yang sederhana tahap kesukarannya. Kebanyakan klausa dan ayat yang terdapat dalam teks ini menggunakan laras bahasa yang mudah dan sederhana, mempunyai maksud yang jelas dan tidak mengandungi unsur-unsur retorik (balāghat ). Walau bagaimanapun, terdapat juga beberapa ayat yang mengandungi frasa penanda wacana di pertengahan ayat yang memisahkan antara subjek dan predikat. Teks ini mengandungi 272 perkataan dan membicarakan tentang peranan keluarga sebagai institusi pendidikan awal seorang anak. Berdasarkan kepada ciri-ciri tersebut, pengkaji mendapati teks ini sesuai untuk menilai pemahaman pelajar terhadap teks bahasa Arab.

Objektif kajian ini adalah untuk mengetahui pemahaman pelajar terhadap teks bacaan, dan seterusnya menganalisis pengaruh unsur subjek dan predikat terhadap pemahaman pelajar. Subjek dan predikat dalam bahasa Arab dikenali sebagai mubtada' dan khabar pada ayat nominal, manakala pada ayat verbal ia dikenali dengan $f i l$ dan $f \bar{a}$ ' $i l$. Kedua-dua unsur ini merupakan unsur asas dalam binaan ayat. Justeru, pelajar perlu memahami dan mengenal pasti kedua-dua unsur ini ketika aktiviti membaca agar pemahaman mereka tidak tersasar daripada maksud teks yang sebenar. Malah, konsep subjek dan predikat ini sangat perlu difahami oleh pelajar bahasa Arab sebelum mereka mendalami ilmu tatabahasa yang lain (Mohd Rosdi 2003).

Untuk mencapai kedua-dua objektif tersebut, kajian ini menggunakan dua kaedah pengumpulan data, iaitu melalui prosedur pemahaman teks secara bertulis, dan temu bual. Soalan pemahaman dibina berdasarkan model pengelasan soalan pemahaman oleh Marohaini (1999). Pengkaji memilih soalan pemahaman berbentuk teks eksplisit yang merupakan tahap paling asas dalam pemahaman. Soalan teks eksplisit dalam kajian ini menggunakan teknik "terjemahan kepada bahasa ibunda" yang diubah suai daripada soalan pemahaman teks pendek (al-Khūlī 2000). Sebanyak tujuh ayat yang merangkumi maksud bagi setiap perenggan dalam teks bacaan ini telah dipilih untuk diuji pemahamannya dalam kalangan peserta kajian.

Prosedur temu bual pula terbahagi kepada dua sesi, iaitu temu bual pemahaman teks dan temu bual pengaruh subjek dan predikat terhadap pemahaman. Melalui temu bual sesi pertama, pengkaji akan meminta peserta kajian menyatakan semula maksud beberapa ayat yang dipilih daripada teks bacaan. Ayat ini merupakan ayat yang sama yang telah dijawab oleh peserta kajian dalam prosedur pemahaman secara bertulis. Manakala, dalam temu bual sesi kedua pula pengkaji mengemukakan beberapa soalan yang berkaitan dengan aplikasi tatabahasa sebagaimana berikut:

1. “Kenapa baca begini (dan begini)?" - Pengkaji merujuk kepada perkataan-perkataan tertentu yang boleh mempengaruhi pemahaman peserta kajian terutama sekali unsur subjek dan predikat.

2. "Perkataan ini berfungsi sebagai apa dalam ayat ini?" - Pengkaji merujuk kepada perkataan-perkataan tertentu. 
3. Soalan-soalan lain yang berkait dengan aplikasi tatabahasa subjek dan predikat dan pemahaman.

4. Bagaimana anda memahami ayat ini?

Kedua-dua prosedur pengumpulan data ini berjalan serentak dan ia sesuai dengan kajian ini yang menggunakan kaedah kualitatif bagi mendapatkan data yang terperinci dan kukuh. Prosedur pengumpulan data bermula dengan peserta kajian membaca teks secara senyap. Seterusnya mereka menjawab soalan pemahaman secara bertulis. Setelah itu, dua sesi temu bual diadakan, iaitu sesi pertama bertujuan untuk memeriksa sekali lagi pemahaman peserta kajian terhadap teks setelah melalui prosedur pemahaman teks secara bertulis. Manakala, sesi kedua pula ialah temu bual untuk melihat pengaruh unsur tatabahasa subjek dan predikat terhadap pemahaman peserta kajian.

\section{DAPATAN KAJIAN}

Setelah menganalisis data yang dikumpulkan daripada prosedur pemahaman teks dan temu bual, pengkaji memperoleh dapatan berdasarkan kepada dua objektif kajian.

\section{DAPATAN PEMAHAMAN TEKS}

Data yang dikumpulkan menunjukkan sebahagian besar peserta kajian dapat memahami teks bacaan dengan baik, terutamanya petikan ayat yang dibina dengan struktur binaan yang mudah ataupun ayat tunggal.

Jadual 1 menunjukkan ayat 1, 2, 3, dan 4 termasuk dalam kategori ayat yang mudah. Struktur ayat tersebut juga dibina dengan susunan biasa yang tiada unsur-unsur taqdìm

JADUAL 1. Pemahaman peserta kajian

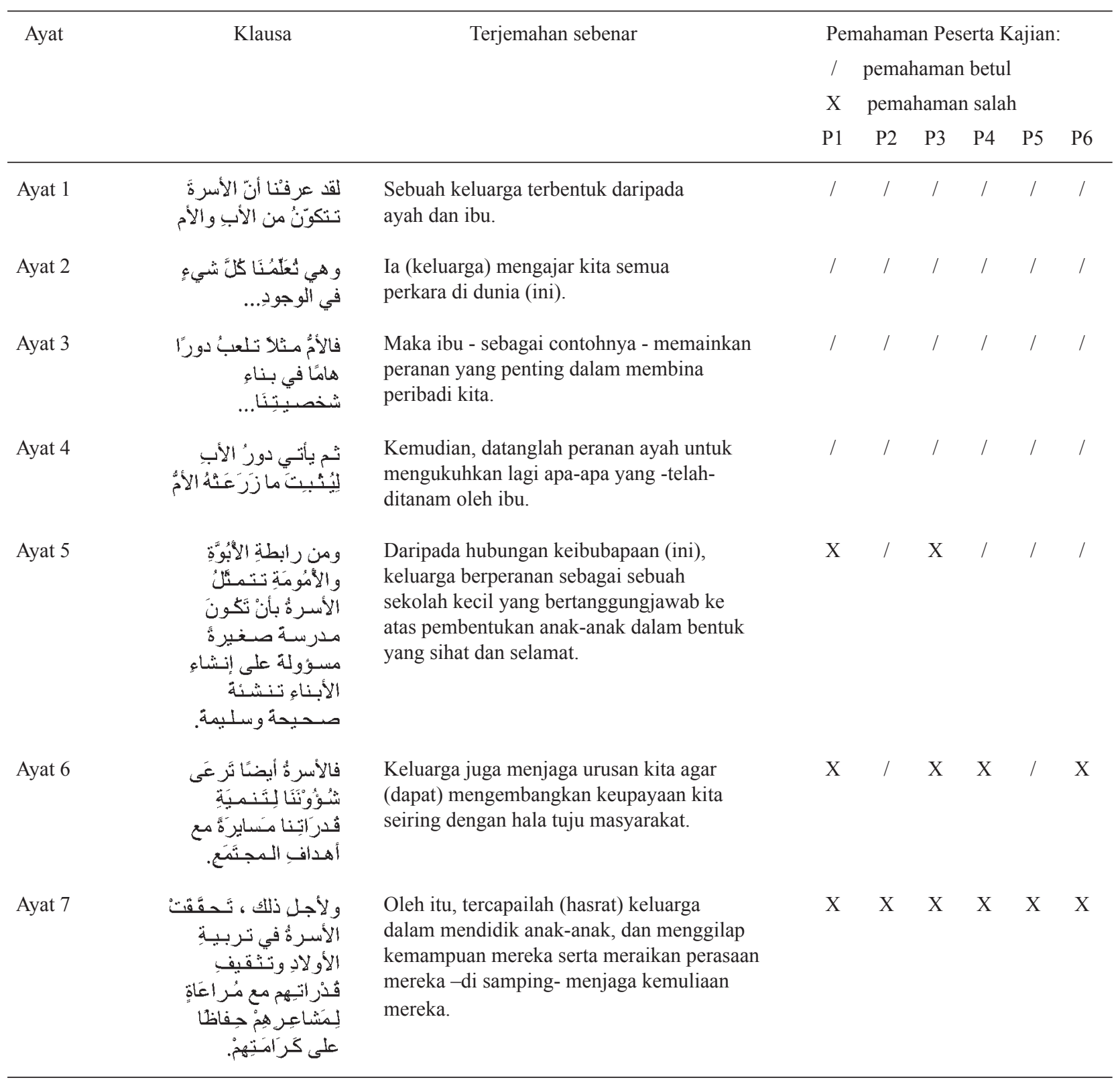


dan $t a$ 'khīr. Oleh itu, semua peserta kajian tidak menghadapi masalah untuk memahami ayat-ayat tersebut.

Ayat 5 juga dapat difahami oleh sebahagian besar peserta kajian kecuali P1 dan P3. Kegagalan P1 dan P3 memahami ayat ini disebabkan oleh frasa penanda wacana yang mengganggu pemahaman mereka. P1 memahami klausa

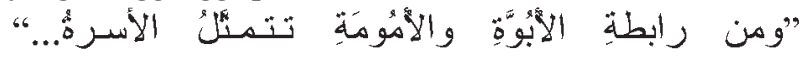
daripada ayat ini dengan maksud: "Dan daripada ikatan ibu bapa itu akan memberi contoh kepada keluarga...”. P3 pula memahaminya dengan maksud: "Dan daripada gabungan ayah dan ibu akan membina tanggungjawab pengajaran dari kecil...". Kedua-dua pemahaman ini menunjukkan P1 dan P3 keliru dengan struktur binaan ayat disebabkan oleh kehadiran frasa

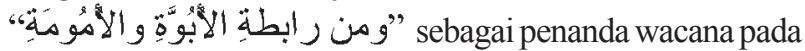
permulaan ayat.

Antara faktor kegagalan peserta kajian memahami teks juga berpunca daripada kelemahan mereka membentuk makna perkataan atau frasa yang menjadi unsur asas binaan ayat subjek dan predikat seperti yang dicatatkan oleh P1, P3, P4, dan P6 terhadap ayat 6. Mereka gagal membentuk makna yang tepat bagi perkataan نَّ عَ عَى dalam ayat tersebut. Begitu juga dengan semua peserta kajian yang gagal memahami ayat 7 dengan tepat disebabkan kelemahan membentuk makna perkataan $\underbrace{ن}$ dengan tepat.

\section{DAPATAN PENGARUH SUBJEK DAN PREDIKAT TERHADAP PEMAHAMAN}

Data juga menunjukkan bahawa wujudnya pengaruh unsur tatabahasa subjek dan predikat dalam pemahaman teks oleh peserta kajian. Dapatan ini diperoleh berdasarkan kewujudan dua fenomena berikut:

1. Pemahaman yang selari dengan aplikasi tatabahasa yang betul.

2. Pemahaman yang selari dengan aplikasi tatabahasa yang salah.

Pemahaman yang selari dengan aplikasi tatabahasa yang betul dicatatkan oleh P1, P2 dan P6 terhadap ayat 2; P1, P2, P4 dan P6 terhadap ayat 3 serta P2 dan P5 terhadap ayat 6 . Pemahaman ini ditunjukkan oleh Jadual 2.

JADUAL 2. Pemahaman selari dengan aplikasi tatabahasa yang betul

\begin{tabular}{|c|c|c|c|}
\hline Ayat & $\begin{array}{l}\text { Peserta } \\
\text { Kajian }\end{array}$ & Pemahaman & $\begin{array}{l}\text { Aplikasi } \\
\text { Tatabahasa }\end{array}$ \\
\hline \multirow[t]{3}{*}{ 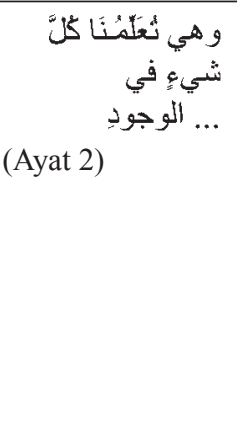 } & P1 & 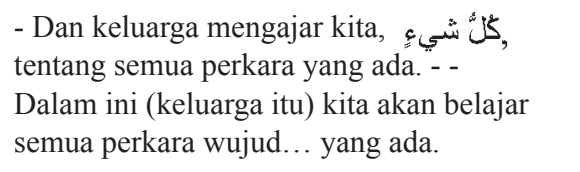 & 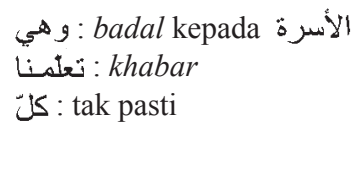 \\
\hline & $\mathrm{P} 2$ & $\begin{array}{l}\text { Keluarga itu telah mengajar kita setiap } \\
\text { perkara yang timbul. }\end{array}$ & 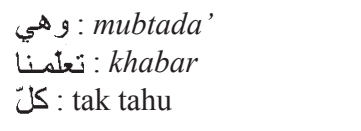 \\
\hline & P6 & $\begin{array}{l}\text { Dan ia (keluarga) mengajar(kan) kami } \\
\text { setiap perkara (sesuatu) dalam } \\
\text { kehidupan. }\end{array}$ & 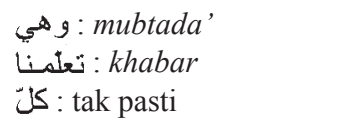 \\
\hline \multirow{4}{*}{ 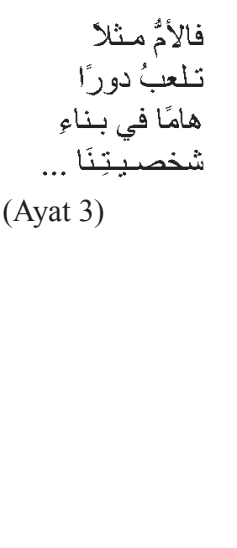 } & P1 & $\begin{array}{l}\text { Maka ibu, contoh(nya), memainkan peranan } \\
\text { penting dalam membentuk peribadi kita. }\end{array}$ & 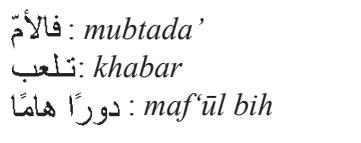 \\
\hline & P2 & $\begin{array}{l}\text { Sebagai contoh, ibu memainkan peranan } \\
\text { yang sangat penting dalam membentuk } \\
\text { peribadi kita. }\end{array}$ & 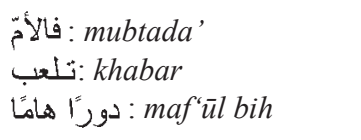 \\
\hline & $\mathrm{P} 4$ & $\begin{array}{l}\text { Ibu memainkan peranan yang penting } \\
\text { dalam membina keperibadian kita. }\end{array}$ & 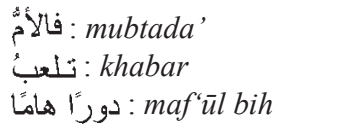 \\
\hline & P6 & $\begin{array}{l}\text { Contohnya ibu (ibu sebagai contohnya), } \\
\text { memainkan peranan penting dalam } \\
\text { membina sahsiah kita (kami). }\end{array}$ & 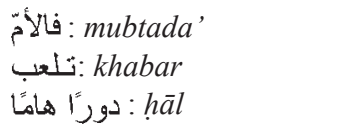 \\
\hline 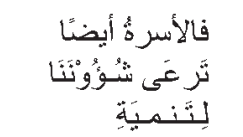 & $\mathrm{P} 2$ & $\begin{array}{l}\text { Keluarga juga memelihara tugas-tugas kita } \\
\text { dalam memudahkan kemampuan kita } \\
\text { dengan tujuan kemasyarakatan. }\end{array}$ & 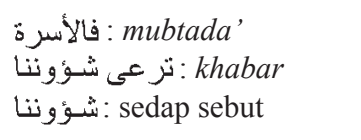 \\
\hline 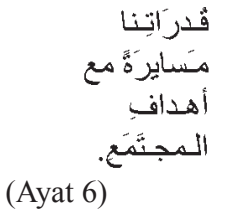 & P5 & $\begin{array}{l}\text { Keluarga juga menjaga hal keadaan } \\
\text { (kebajikan) kita untuk meningkatkan } \\
\text { kemampuan kita bersama/serta tujuan } \\
\text { sebuah masyarakat. (مُسَرَ) tidak tahu } \\
\text { makna/tidak diterjemahkan) }\end{array}$ & $\begin{array}{l}\text { : فالأسرة : mabtada' } \\
\text { : شرعـى : maf'ūl bih }\end{array}$ \\
\hline
\end{tabular}


Jadual 2 menunjukkan bahawa P1, P2 dan P6 dapat memahami ayat 2 selari dengan aplikasi tatabahasa oleh mereka dan aplikasi ini menepati konteks tatabahasa sebenar serta menepati konteks ayat. P1 memahami klausa "و هي تعلمنا" dengan maksud, "Dan keluarga mengajar kita,.." dan pemahaman ini selari dengan aplikasi tatabahasa yang mengatakan وهي ialah badal kepada الأسرة pula ialah khabar. Walaupun aplikasi P1 yang mengatakan وهي تون merupakan badal kepada الأسرة adalah kurang tepat, tetapi kesalahan ini dikira sebagai kesalahan kecil kerana maksud وهي dikaitkan dengan الأسرة. P2 pula memahami klausa ini dengan maksud, "Keluarga itu telah mengajar kita..." dan pemahaman ini selari dengan aplikasi tatabahasanya yang mengatakan تعلمـنا ialah mubtada', manakala pula ialah khabar. Begitu juga pemahaman P6 terhadap klausa ini yang selari dengan aplikasi tatabahasanya yang betul.

Jadual 2 juga menunjukkan bahawa pemahaman yang selari dengan aplikasi tatabahasa yang betul bagi ayat 3 . Pengkaji memfokuskan kepada pemahaman P1, P2, P4 dan P6 yang dapat mengenal pasti subjek dan predikat dalam ayat ini walaupun dipisahkan oleh penanda wacana مثنل . Walaupun maksud yang diberikan kepada perkataan منثلا dalam ayat ini adalah berbagai-bagai, tetapi ia menunjukkan bahawa peserta kajian dapat memahaminya berfungsi sebagai penanda wacana dan bukan subjek ataupun predikat. Begitu juga P2 dan P5 yang memahami struktur ayat 6 dan dapat membentuk makna perkataan dengan betul bagi membina maksud ayat ini.
Pemahaman yang selari dengan aplikasi tatabahasa yang salah oleh peserta kajian pula menunjukkan bahawa faktor tatabahasa sememangnya mempengaruhi pemahaman peserta kajian. Pemahaman yang selari dengan aplikasi tatabahasa yang salah ini ditunjukkan oleh Jadual 3 di bawah.

Berdasarkan Jadual 3, P1 memahami ayat 5 dengan maksud, "Dan daripada ikatan ibu bapa itu akan memberi contoh kepada keluarga...". Pemahaman ini selari dengan aplikasi tatabahasa oleh beliau yang mengatakan bahawa

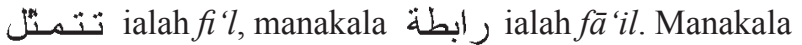
P2 pula memahami ayat ini dengan maksud, "Daripada ikatan ibu bapa ini menggambarkan bahawa keluarga merupakan sekolah kecil...". Ia juga selari dengan aplikasi tatabahasa oleh beliau yang mengatakan bahawa تنـمـن ialah fi’l mudāri ' dan ومن رابطة الأبوة والأمومة ialah fà'il.

P5 pula memahami ayat 3 dengan maksud, "Ibu merupakan contoh yang memainkan peranan yang penting". Pemahaman ini selari dengan aplikasi tatabahasa oleh beliau yang mengatakan bahawa فالأم ialah mubtada', manakala "منتل تلعب دوررًا هايًا" ialah khabar. Begitu juga dengan P6 yang memahami ayat 7 dengan maksud, "Di samping itu, saya menegaskan (bahawa) keluarga dalam mendidik anak-anak.....". Pemahaman ini menunjukkannya selari dengan aplikasi tatabahasa oleh beliau yang mengatakan bahawa تـحقّقت ialah $f i^{\prime} l$ dan $f a ̄ ' i l$, manakala الأسـرة ialah maf'ūl bih.

JADUAL 3. Pemahaman selari dengan aplikasi tatabahasa yang salah

\begin{tabular}{|c|c|c|c|}
\hline Ayat & $\begin{array}{l}\text { Peserta } \\
\text { Kajian }\end{array}$ & Pemahaman & $\begin{array}{c}\text { Aplikasi } \\
\text { Tatabahasa }\end{array}$ \\
\hline 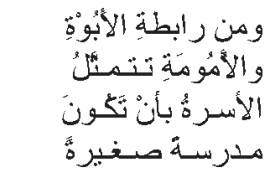 & P1 & 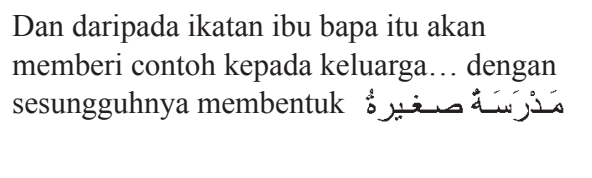 & 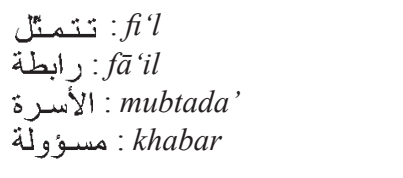 \\
\hline 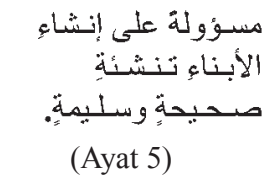 & P2 & $\begin{array}{l}\text { Daripada ikatan ibu bapa ini menggambarkan } \\
\text { bahawa keluarga merupakan sekolah kecil } \\
\text { yang bertanggungjawab dalam pembentukan } \\
\text { anak-anak.... }\end{array}$ & 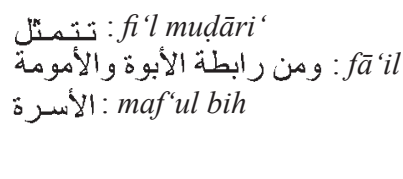 \\
\hline 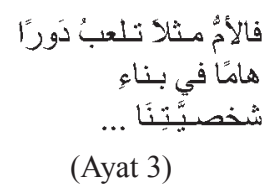 & P5 & $\begin{array}{l}\text { Ibu merupakan contoh yang memainkan } \\
\text { peranan yang penting dalam pembentukan } \\
\text { sahsiah kita. }\end{array}$ & 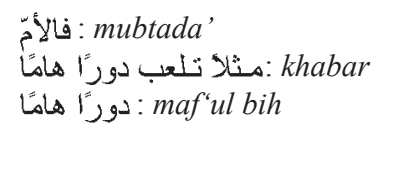 \\
\hline 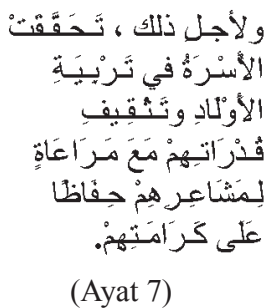 & P6 & $\begin{array}{l}\text { Di samping itu, saya menegaskan (bahawa) } \\
\text { keluarga dalam mendidik anak-anak..... }\end{array}$ & 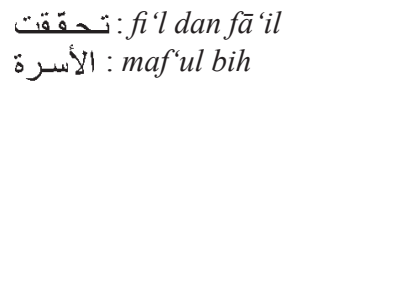 \\
\hline
\end{tabular}


Data yang ditunjukkan dalam Jadual 3 menunjukkan bahawa aplikasi tatabahasa yang salah telah dipraktikkan oleh peserta kajian. Walau bagaimanapun, keserasian yang wujud antara pemahaman dan aplikasi tatabahasa oleh mereka menunjukkan wujudnya pengaruh unsur tatabahasa dalam pemahaman.

\section{KESIMPULAN}

Kajian ini menunjukkan bahawa peserta kajian dapat memahami teks dengan baik bagi klausa yang berbentuk ayat mudah dan tidak mengandungi unsur-unsur lain yang boleh mengganggu pemahaman mereka seperti frasa penanda wacana. Selain itu, peserta kajian kadang-kadang menghadapi masalah untuk memahami ayat yang mudah disebabkan oleh kegagalan membentuk makna yang tepat dan sesuai bagi perkataan-perkataan tertentu yang merupakan unsur asas binaan ayat.

Kajian ini juga mendapati wujudnya pengaruh unsur tatabahasa dalam pemahaman teks oleh peserta kajian berdasarkan fenomena pemahaman yang selari dengan aplikasi tatabahasa yang betul dan pemahaman yang selari dengan aplikasi tatabahasa yang salah. Kedua-dua fenomena ini menunjukkan bahawa unsur tatabahasa terutamanya unsur binaan asas ayat, iaitu subjek dan predikat mempengaruhi pemahaman peserta kajian. Malah, ia sangat membantu pemahaman terhadap ayat yang sedikit sukar seperti ayat yang mengandungi frasa penanda wacana yang boleh mengelirukan pemahaman.

Justeru, semasa aktiviti membaca, pelajar perlu mengenal pasti subjek dan predikat yang merupakan unsur asas binaan ayat. Mereka perlu memahami bahawa sekiranya tiada subjek dan predikat maka sesuatu ayat itu tidak bermakna. Begitu juga sekiranya mereka gagal untuk mengenal pasti subjek dan predikat dengan tepat boleh menyebabkan pemahaman yang salah mengikut konteks tatabahasa. Selain itu, pelajar juga perlu mampu untuk membentuk makna perkataan yang tepat dan sesuai bagi memastikan pemahaman yang baik dapat dicapai mengikut konteks ayat. Oleh itu, proses pengajaran dan pembelajaran bahasa Arab khususnya yang melibatkan kemahiran membaca perlu memberi penekanan kepada pelajar untuk mengenal pasti subjek dan predikat dalam satu-satu ayat selain daripada penguasaan kosa kata yang baik bagi memahami dengan tepat makna perkataan yang menjadi unsur subjek dan predikat.

Ahmad Fuad Che Daud @ Che Mud

Sekolah Menengah Kebangsaan Agama

Slim River

35800 Slim River, Perak,

Malaysia

\section{RUJUKAN}

'Abd al-Hāsib, 'U. 2011. Memahami Teks Arab: Sebuah Pengantar. http://elhasib.wordpress.com/2011/09/11/ memahami-teks-arab-sebuah-pengantar/\#more-26. Akses pada 10 November 2011.

al-Khūlī, M.A. 2000. al-'Ikhtibārāt al-Lughawiyyaț. Suwayliḥ: Dār al-Falāh.

Kamarulzaman Abdul Ghani. 2010. Kebolehbacaan Buku Teks Bahasa Arab Tinggi Tingkatan Empat Sekolah Menengah Kebangsaan Agama. Tesis PhD, Universiti Malaya, Kuala Lumpur, Malaysia.

Kamarulzaman Abdul Ghani. 2011. Kebolehbacaan buku teks bahasa Arab tinggi berasaskan ujian kloz dalam kalangan pelajar di SMKA. Gema Online Journal of Language Study 11(2): 53-66.

Karkhī, A.A. 1993. al-Taqniyyāt al-Hadīthaț Fi Ta' līm al-Lughat al-'Arabiyyat Li Ghayr al-'Arab. Majalah Pengajian Arab 3(3): 7-35.

Marohaini Yusof. 1999. Strategi Pengajaran Bacaan dan Kefahaman. Kuala Lumpur: Dewan Bahasa dan Pustaka.

Mohd Rosdi Ismail. 2003. Bahasa Arab Mikro: Binaan Kata dan Fungsi Makna. Kota Bharu: Arabic Language and Consultancy.

Nik Farhan Mustapha. 2011. 'Istirātijiyyāt al-Qira'at ladā Ṭalabat al-Lughat al-'Arabiyyaț. Tesis PhD, Universiti Islam Antarabangsa Malaysia, Kuala Lumpur, Malaysia.

Nik Mohd Rahimi Nik Yusof \& Sarizan Sulong. 2013. Tahap Kefahaman Bacaan Bahasa Arab. Proses Pendidikan Sepanjang Hayat: 226-235.

Norazman Mohd Nordin. 2006. Penguasaan Kemahiran Membaca dalam Bahasa Arab: Satu Kajian Kes. Disertasi Sarjana, Universiti Malaya, Kuala Lumpur, Malaysia.

Rosni Samah. 2009. Pendekatan Pembelajaran Kemahiran Bahasa Arab untuk Pelajar Bukan Penutur Jati. Nilai: Penerbit Universiti Sains Islam Malaysia.

Tu'aymaț, R.A. 1990. Al-Mahārāt Al-Lughawiyyaț wa mustawayātuhā: Tahlīl Nafs Lughawī Dirāsat Maydāniyyaț. Makkat al-Mukarramaț: Jāmi'at 'Umm al-Qurā.

Yahya Othman. 2004. Mengajar Membaca: Teori dan Aplikasi: Panduan Meningkatkan Kemahiran Mengajar Membaca. Bentong: PTS Publications and Distributors Sdn. Bhd.

Zulazhan Ab Halim, Zamri Arifin \& Kaseh Abu Bakar. 2009. Ujian Kloz dan Hubungannya dengan Kebolehbacaan Buku Teks Bahasa Arab. Nadwah Bahasa dan Kesusasteraan Arab Kedua: Ke Arah Melestarikan Bahasa dan Kesusasteraan Arab di Malaysia. 10-11 Oktober. Serdang, Selangor, Malaysia. 297-311.

*Pengarang untuk surat-menyurat; email: abufaiz08@gmail. com

Diserahkan: 3 September 2014

Diterima: 5 Januari 2015 